\title{
Controlled trial of sodium valproate in severe epilepsy
}

\author{
ALAN RICHENS, SUHAIL AHMAD
}

being administered. Throughout the trial the patients' existing treatment was continued unchanged unless drowsiness occurred, in which case the dose of phenobarbitone or primidone was reduced.

We assessed the response to the drug by recording the major and minor fits that occurred each week of the trial. Although the staff in charge of the residential houses and work centres were trained in observing and recording fits, some fits, particularly minor ones, went unrecorded. This deficiency, however, should have occurred equally in the placebo and active drug treatment periods. Fits were assessed as two types: tonic-clonic seizures ("major" attacks); and all other types, including absence attacks, adversive attacks, and focal and psychomotor fits ("minor" attacks). To examine the possibility of drug interaction serum phenytoin and phenobarbitone levels were measured by enzyme immunoassay in seven patients before administration of sodium valproate and at the end of the assessment period in which the active drug had been used. Furthermore, tracer doses of ${ }^{14} \mathrm{C}$-labelled phenytoin were given by mouth before and during sodium valproate treatment to measure the serum half life of the carbon label. ${ }^{5}$

\section{Results}

Control of fits-The effect of sodium valproate compared with placebo is shown in tables III and IV. These results were significantly in favour of sodium valproate (for major fits, $\mathrm{P}<0.05$; for minor fits, $\mathrm{P}<0.01$, using Wilcoxon signed-ranks test). The significance of the differences was confirmed by an analysis of variance. The frequency of major fits during valproate treatment was reduced to an average of $35^{\circ}$ of the frequency on placebo. The corresponding reduction in minor fits was to $57 \%$ of the frequency on placebo.

Adverse effects-Thirteen patients showed signs of toxicity, comprising drowsiness, ataxia, and nausea (table III). These signs were usually mild and transient, however, and did not necessitate withdrawal of the test drug in any patient. In only three patients was it necessary to reduce the dose of primidone or phenobarbitone because of drowsiness, but in one of these it was discovered on breaking the code that the patient was receiving placebo at the time of drug reduction.

Interaction with phenobarbitone and phenytoin-Serum phenobarbitone levels measured in duplicate or triplicate showed a consistent rise in each of seven patients in whom the estimations were performed. The average increase was $27 \%$ (from 95 to $121 \mu \mathrm{mol} / 1$ (22 to 28 $\mu \mathrm{g} / \mathrm{ml}$ )) with a range of $17-48 \%$, and was statistically significant $(\mathrm{P}<0.02$, Wilcoxon test). Serum phenytoin levels were measured in six patients, but no consistent change was observed. The serum half life of a tracer dose of phenytoin shortened in two patients and lengthened in five (not significant).

\section{Discussion}

Sodium valproate in a fixed dose of $1200 \mathrm{mg} /$ day significantly reduced the frequency of both tonic-clonic and minor seizures when added to the existing treatment of 20 severely epileptic patients whose fits had proved difficult to control with the established drugs.

In three patients no response to sodium valproate was seen, and in three others the frequency of one type of seizure decreased while that of another increased. Apart from one patient who had an extensive right hemisphere lesion from a depressed skull fracture (case 15) these therapeutic failures occurred in patients with temporal lobe lesions. As 11 of our patients had this type of lesion firm conclusions about the response of different types of epilepsy cannot be drawn from our results, though Jeavons and Clark ${ }^{6}$ have noted a poor response in patients with temporal lobe lesions.

Because sodium valproate or placebo were added to existing treatment we cannot say whether the anticonvulsant effect

National Hospitals Special Centre for Epilepsy, Chalfont St Peter, Buckinghamshire, SL9 0RJ

SUHAIL AHMAD, BSC, MB, assistant physician 
TABLE I-Details of patients included in trial

\begin{tabular}{|c|c|c|c|c|c|c|c|}
\hline \multirow{2}{*}{ Case No. } & \multirow{2}{*}{$\begin{array}{c}\text { Age } \\
\text { and sex }\end{array}$} & \multirow{2}{*}{ Type of epilepsy } & \multicolumn{5}{|c|}{ Drug Treatment (mg/day) } \\
\hline & & & Phenytoin & Phenobarbitone & Primidone & Carbamazepine & Others \\
\hline $\begin{array}{r}1 \\
2 \\
3 \\
4 \\
5 \\
6 \\
7 \\
8 \\
9 \\
10 \\
11 \\
12 \\
13 \\
14 \\
15 \\
16 \\
17 \\
18 \\
19 \\
20\end{array}$ & $\begin{array}{ll}22 & M \\
24 & M \\
40 & M \\
29 & M \\
28 & F \\
34 & M \\
38 & F \\
19 & M \\
23 & M \\
54 & M \\
20 & M \\
21 & M \\
41 & M \\
21 & M \\
28 & M \\
29 & M \\
37 & F \\
28 & M \\
24 & M \\
29 & M\end{array}$ & 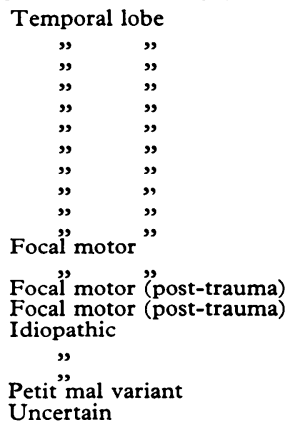 & $\begin{array}{l}400 \\
300 \\
300 \\
200 \\
300 \\
300 \\
400 \\
250 \\
300 \\
300 \\
200 \\
400 \\
300 \\
200 \\
300 \\
300 \\
300 \\
300\end{array}$ & $\begin{array}{l}180 \\
180 \\
180 \\
120 \\
180 \\
180 \\
150 \\
\\
150\end{array}$ & $\begin{array}{r}1000 \\
1000 \\
1500 \\
750 \\
1500 \\
1000 \\
1000 \\
750 \\
750 \\
1000 \\
1000 \\
1000\end{array}$ & $\begin{array}{l}800 \\
600 \\
400 \\
400 \\
400 \\
\\
600\end{array}$ & $\begin{array}{l}\text { Chlordiazepoxide } 10 \\
\text { Diazepam } 6 \\
\text { Diazepam } 15 \\
\text { Ethosuximide } 750 \\
\text { Diazepam } 6 \\
\text { Sulthiame } 200 \\
\text { Pheneturide } 400 \\
\text { Ethosuximide } 1500 \\
\text { Diazepam 4, pheneturide } 600 \\
\text { Ethosuximide } 750\end{array}$ \\
\hline
\end{tabular}

TABLE II-Dosage scheme used in trial. Each tablet of sodium valproate contained $200 \mathrm{mg}$ of the drug

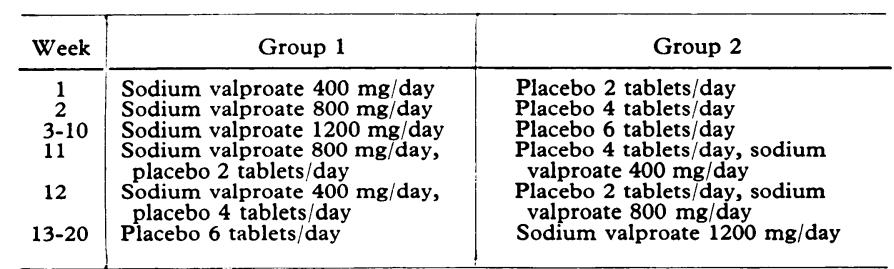

TABLE III-Response and adverse effects to sodium valproate treatment

\begin{tabular}{|c|c|c|c|c|c|}
\hline \multirow{3}{*}{$\begin{array}{l}\text { Case } \\
\text { No }\end{array}$} & \multicolumn{4}{|c|}{$\begin{array}{c}\text { No of fits in } 8 \text {-week assessment } \\
\text { period }\end{array}$} & \multirow{3}{*}{ Adverse effects on valproate } \\
\hline & \multicolumn{2}{|c|}{ Placebo } & \multicolumn{2}{|c|}{ Valproate } & \\
\hline & Major & Other & Major & Other & \\
\hline $\begin{array}{r}1 \\
2 \\
3 \\
4 \\
5 \\
6 \\
7 \\
8 \\
9 \\
10 \\
11 \\
12 \\
13 \\
14 \\
15 \\
16 \\
17 \\
18 \\
19 \\
20\end{array}$ & $\begin{array}{l}5 \\
0 \\
9 \\
6 \\
0 \\
0 \\
5 \\
0 \\
6 \\
1 \\
5 \\
0 \\
0 \\
0 \\
0 \\
7 \\
0 \\
0 \\
4 \\
7\end{array}$ & $\begin{array}{r}37 \\
52 \\
63 \\
2 \\
25 \\
29 \\
15 \\
52 \\
19 \\
12 \\
7 \\
9 \\
65 \\
52 \\
6 \\
17 \\
54 \\
27 \\
36 \\
5\end{array}$ & $\begin{array}{l}0 \\
0 \\
0 \\
0 \\
0 \\
0 \\
0 \\
3 \\
5 \\
0 \\
6 \\
0 \\
0 \\
0 \\
1 \\
0 \\
0 \\
0 \\
2 \\
2\end{array}$ & $\begin{array}{r}5 \\
22 \\
41 \\
4 \\
32 \\
20 \\
10 \\
25 \\
17 \\
14 \\
8 \\
8 \\
30 \\
22 \\
11 \\
1 \\
31 \\
15 \\
13 \\
5\end{array}$ & $\begin{array}{l}\text { Initial drowsiness } \\
\text { Initial drowsiness and nausea } \\
\text { Initial drowsiness and nausea } \\
\text { Transient ataxia } \\
\text { Initial drowsiness and nausea } \\
\text { Transient ataxia } \\
\text { Initial drowsiness } \\
\text { Initial drowsiness and nausea } \\
\text { Initial drowsiness and nausea }\end{array}$ \\
\hline Total & 55 & 584 & 19 & 334 & \\
\hline
\end{tabular}

*Phenobarbitone discontinued during valproate treatment.

†Phenobarbitone reduced during placebo treatment.

TABLE IV-Summary of response to sodium valproate

\begin{tabular}{|c|c|c|c|c|c|}
\hline \multicolumn{3}{|c|}{ Type of fit } & Better & Unchanged & Worse \\
\hline $\begin{array}{l}\text { Major } \quad \ldots \\
\text { Minor } \\
\text { Combined }\end{array}$ & & $\begin{array}{l}\cdots \\
\cdots\end{array}$ & $\begin{array}{r}9 \\
14 \\
16\end{array}$ & $\begin{array}{l}8 \\
1 \\
0\end{array}$ & $\begin{array}{l}3 \\
5 \\
4\end{array}$ \\
\hline
\end{tabular}

that we have shown was the result of a pharmacological action of sodium valproate itself or of an increase in the serum concentration of phenobarbitone. In the seven patients whose phenobarbitone levels were measured a rise was seen at the end of the eight-week assessment period, though the average increase was only $27 \%$. Similar observations have been made in three patients by Schobben et al. ${ }^{7}$ This rise may well explain the initial drowsiness and ataxia which often occurs when adding sodium valproate to existing phenobarbitone or primidone treatment; this was seen in 12 of our patients. If the dose of phenobarbitone or primidone is reduced the toxic symptoms abate rapidly. In contrast, sodium valproate had little effect on phenytoin metabolism in the patients in whom this was studied. No consistent change in serum phenytoin levels or half lives was seen.

The dose of sodium valproate used in this trial was not large; the plasma levels of valproate found in four patients in whom they were measured ranged from 237-475 $\mu \mathrm{mol} / 1(34-68 \mu \mathrm{g} / \mathrm{ml})$ and were within the range expected from a dose of $1200 \mathrm{mg} /$ day. A "therapeutic range" of $350-700 \mu \mathrm{mol} / 1(50-100 \mu \mathrm{g} / \mathrm{ml})$ has been cited by Schobben et $a l,{ }^{7}$ though no prospective studies have been performed to establish such a range.

The patients selected for this trial had severe epilepsy that had responded inadequately to various combinations of established drugs. The useful therapeutic effect that was produced by sodium valproate in these patients is therefore promising. Further controlled trials are necessary, however; firstly, to establish the part played by concurrent phenobarbitone or primidone treatment in the therapeutic response to valproate; and, secondly, to compare its efficacy with other established drugs used for the various types of epilepsy.

We thank Dr John Laidlaw, senior physician at the Chalfont Centre, for allowing us to study patients under his care; the nursing staff at the centre for their co-operation; Dr Richard Smith, Dr Bernard Jordan, and Dr Paul Bevan, of Reckitt and Colman Limited, for supplies of sodium valproate (Epilim) and placebo and for valproate measurements; Mrs Monica Hetherington for her invaluable technical help; and Miss Monica Leighton for statistical help.

\section{References}

1 Meunier, H, et al, Therapie, 1963, 18, 435.

2 Völzke, E, and Doose, H, Epilepsia, 1973, 14, 185.

${ }^{3}$ Kugler, J, Knorl, G, and Empt, J, Münchener medizinische Wochenschrift, 1973, 115, 1103.

4 Meinardi, H, Clinical trials of antiepileptic drugs. Psychiatry, Neurology and Neurosurgery, 1971, 74, 141.

${ }^{5}$ Houghton, G W, and Richens, A, British fournal of Clinical Pharmacology, $1974,1,155$.

6 Jeavons, P M, and Clark, J E, British Medical fournal, 1974, 2, 584.

7 Schobben, F, Kleijn, E van der, and Gabreels, F J M, European fournal of Clinical Pharmacology, 1975, 8, 97. 